\title{
Properties of Sand Cement Brick Containing Quarry Dust (SCBQD) and Bacteria Strain
}

\author{
J.M. Irwan ${ }^{1 *}$, N. Othman ${ }^{2}$, H.B. Koh ${ }^{1}$ \\ ${ }^{1}$ Jamilus Research Centre for Sustainable Construction (JRC), \\ Faculty of Civil Engineering and Built Environment, \\ Universiti Tun Hussein Onn Malaysia, 86400, Parit Raja, Johor, MALAYSIA \\ ${ }^{2}$ Micro-Pollutant Research Centre (MPRC), \\ Faculty of Civil Engineering and Built Environment, \\ Universiti Tun Hussein Onn Malaysia, 86400, Parit Raja, Johor, MALAYSIA \\ *Corresponding Author
}

DOI: https://doi.org/10.30880/ijscet.2020.11.02.002

Received 30 July 2020; Accepted 30 August 2020; Available online 02 September 2020

\begin{abstract}
Sand cement brick among favorable building material for low cost house construction due to its low price. Technology development in building material already explored varies waste to be added in improving properties of building materials. Beside that addition of bacteria in building material also proven in literature to improve its properties. In this research addition of bacteria in the cement sand block containing quarry dust (SCBQD) was studied. Several properties namely, compressive strength, depth of carbonation, initial rate of suction (IRS) and water absorption were studied. SCBQD is made from sand, cement, quarry dust and chipping using industrial mix design. In this study, 3\% of Enterococcus faecalis (EF) and 5\% of Bacillus sp (BSP) bacteria was added in the SCBQD mixes. Three SCBQD mixes were prepared including the control mix without bacteria, SCBQD with $3 \% \mathrm{EF}$ and SCBQD with 5\% BSP. Natural fine aggregate was replaced partially with the quarry dust. $100 \mathrm{~mm}$ SCBQD cubes were used to conduct compressive strength, depth of carbonation, initial rate of suction and water absorption test at 7,14 and 28 days. The experimental results showed that the compressive strength value of SCBQD with addition of bacteria was increased for all curing ages. At 28 days of curing, the compressive strength value for control SCBQD containing quarry without any addition of bacteria is $3.30 \mathrm{MPa}$, while SCBQD containing quarry dust with addition of $3 \%$ of EF bacteria is $3.57 \mathrm{MPa}$ and for SCBQD with $5 \%$ of $\mathrm{BSP}$ bacteria the value is $4.90 \mathrm{MPa}$. On the other hand, SCBQD containing 3\% EF and 5\% BSP gained lower IRS and carbonation depth. Depth of carbonation at 28 days was decreased $9.3 \%$ and $20 \%$ for SCBQD containing 3\% EF and 5\% BSP, respectively. Meanwhile, 28-day IRS was reduced $12.9 \%$ and $22.6 \%$ for SCBQD containing 3\% $\mathrm{EF}$ and 5\% BSP, respectively. In overall, the result shows that, SCBQD with 5\% BSP as proven positive and better results when compared to control SCBQD and SCBQD with 3\% EF bacteria which is absorb of $12.02 \%$ in water absorption. The findings showed that bio-SCBQD containing industrial waste and bacteria has good potential to be used as building material.
\end{abstract}

Keywords: bio-concrete, concrete properties, industrial waste 


\section{Introduction}

Sand cement bricks are a prefabricated material mainly used to build walls like bricks, where blocks are stacked together and joined with a mortar. Mortar used in the sand cement brick is differ from mortar used in masonry works where the mortar used in sand cement brick has low cement content usually in range 6\% (Ventakarama Reddy \& Jagadish, 2003) and low water cement ratio enable to form the required shape after compaction. Generally, sand cement brick is cheap. Addition of waste material can reduce the cost of sand cement brick production. Usage of ordinary mixture in sand cement brick alone does not enough due to its weaknesses. According to Irwan and Othman (2013), plain sand cement brick is porous, possesses very low tensile strength, limited ductility and little resistance to crack. Extensive studies were carried out in sand cement brick with desired to gain a high performance sand cement brick. One of the attempts is by adding other material in sand cement brick as partial replacement or added material for increasing sand cement brick properties.

Quarry dust is a by-product material that obtained during the quarrying process. Quarry is one of the important sectors that contribute to the country's economy engaged in the production of materials such as granite, limestone, marble and others. Quarry dust is generated during the mining process. Issue related to quarry dust is due to improper disposal method and end up to environmental load to receiving environment. An option to overcome this problem is by using quarry dust as a replacement to river sand that gives additional benefit to concrete (Sukesh, Krishna, Sai Teja \& Rao, 2013). Quarry dust is one of the potential materials that can be used in sand cement brick due to its properties like natural sand (Irwan \& Othman, 2013). Besides that, it is known as the ability to increase strength of concrete higher than concrete made with the same quantities of river sand. Other than that, it also, cause the decrease in the workability of concrete (Joseph, Maurice \&Godwin, 2012). In term of size, the finer fraction is usually smaller than $5 \mathrm{~mm}$ in size (Manning \& Vetterlein, 2004). The smaller size has recently gained attentions to be used as a concrete filler especially as fine aggregates (Sivakumar, 2011).

Technology development in concrete world showed that bacterial is capable to enhance production of calcium carbonate in the form of calcite during microbial metabolic process and resulted to rise up alkalinity suitable for concrete environment and also improved concrete properties due to microbial calcite precipitation (Ramachandran, Ramakrishnan \& Bang, 2001). Scientific development published many examples of bacteria that resemblance function as calcium carbonate/calcite production in concrete environment like, Bacillus Sphaericus that is able for precipitating calcium carbonate (Anneza, Irwan, Othman, \& Alshalif, 2016). Ramachandran et al. (2001) revealed that addition of Bacillus sp increased compressive strength of concrete due to calcite production.

Arunachalam et al. (2010) revealed that the compressive strength of the remediated cubes was found to increase considerably after cubes of concrete were applied with the bio-formed concrete (with addition of Bacillus sphaericus) Effect of microbes on compressive strength of cement mortar cubes at age of 7 th and 28th days studied by Ramachandran et al. (2001) found that inclusion of Bacillus sp. enhanced the compressive strength.

Chahal et al. (2012) studied effect of $S$. pasteurii bacteria on compressive strength of concrete. Addition of bacteria in his study showed that compressive strength of fly ash concrete increased in the case of bacteria cell concentration up to $10^{5}$ cells $/ \mathrm{ml}$. Increase of compressive strength is due to filling of the pores inside cement mortar cubes with microbiologically induced calcium carbonate precipitation.

Effect of microbial concrete also was studied on permeation properties. De Muynck et al. (2008) studied effect of bio-deposition of calcite on permeability characteristics of mortar by B. sphaericus. Presence of biomass contributed to a large extent in the overall decrease of the gas permeability. This scenario proven that increased of concrete properties like compressive strength is due to decrease of pores in concrete by microbial precipitation and and resulted to decrease gas permeability.

The above discussion discovered that microbial (bacterial) calcite precipitation from biological activities of microbial has a great potential to enhance overall concrete properties. It is also proven that urease enzyme existent in microbial breaks down urea to produce carbonate and in present of a calcium in concrete through calcite precipitation under concrete environment. Exploration of bio-concrete properties was also done on other properties like water absorption by Chahal et al., (2012) and Siddique (2011).

Bacteria cell are known as prokaryotes due to genetic material is not encircle in a special nuclear membrane. It has a large range of shapes, ranking from spheres to rods and spirals and ubiquitous in every habitat on earth, growing in soil, acidic hot springs, radioactive waste, water, and deep in the earth crust also in organic matter and the live bodies of plants and animals. There are commonly million bacterial cells in a gram of soil, million in a mililiter of fresh water.and other parts of environment Certain bacteria has not been identified, and many of bacteria species has been grown in the laboratory. Therefore, it is very important to acclimatize those bacteria in the laboratory until optimum growth condition especially before addition in concrete for ensuring its survival in concrete environment with or without addition of other waste materials.

The findings of previous researches had triggered to study on bio-sand cement brick in civil engineering construction materials. The use of bacteria in the production of sand cement brick can overcome the issues arising in plain sand cement brick with properties of porous, possessed very low tensile strength, limited ductility and little resistance to cracking. Exploring quarry dust as a waste material is seem more environmental friendly approach compare to dispose of method to landfill or other receiving environments. Therefore, the properties of sand cement 
brick containing quarry dust (SCBQD) with the addition of different bacteria species was studied. This research also focusing in studying on compressive strength, carbonation, initial rate of suction and water absorption.

\section{Experimental Program}

Optimum growth condition was a first attempt before using the bacteria in SCBQD. Optimal growth need to be measured for ensuring high survival of the bacteria after the addition in the SCBQD. Optimum growth condition was measured throughout enrichment process. The enrichment process is important in order to simulate the condition for the bacteria to grow in SCBQD environment. This was to ensure that the bacteria can acclimatize with addition of quarry dust. Two sets of bacteria enrichment were prepared namely control and treatment specimen. The composition of the treatment enrichment consists of $300 \mathrm{ml}$ nutrient broth added with $120 \mathrm{ml}$ of $40 \%$ urea, $1 \mathrm{mg}$ of quarry dust substances and lastly 1 cyrogenic bead of ureolytic bacteria. The differences between the compositions of control were the enrichment was done without the quarry dust sample. The method of enrichment process follows the previous study (Irwan et al., 2016), (Othman et al., 2017) by adjusting the $\mathrm{pH}$ in alkaline and anaerobic condition for ensuring the survival of EF and BSP bacteria with addition of quarry dust.

Several properties test were run for SCBQD samples. The tests are compressive strength, carbonation test, initial rate of water absorption and water absorption test. In order to run the test, 81 samples were fabricated. All samples were molded with size $100 \mathrm{~mm} \times 100 \mathrm{~mm} \times 100 \mathrm{~mm}$. The samples were cured and tested at 7 th, 14 th and $28 \mathrm{th}$ days. The compressive strength and carbonation testing was conduct according to BS EN 12390-3:2009 and BS EN 14630:2006 respectively. The initial rate of water absorption was done according to ASTM C1585 - 04 to determine the ability of SCBQD to allow the water to pass through it in 1 minute whereas the water absorption test conducted to determine the saturation coefficient which is defined as the percentage of pore volume filled in 24-hour of soaking. The water absorption test conducted according to BS 1881-122:2011. In this study three different batches were prepared namely, $0 \%$ (control), 3\% EF and 5\% BSP which was partially replaced of water during SCBQD production. The mix proportions of materials were according to the desired mix proportion of material from the industry. The mix proportion of materials is shown in Table 1. All batches were tested with a total of three samples for each test and batches.

Table 1 - Mix proportion of materials for one unit of mortar cube

\begin{tabular}{|c|c|c|c|c|c|c|c|}
\hline Type of mortar & 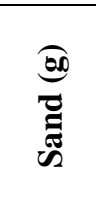 & 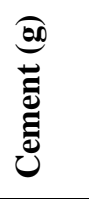 & 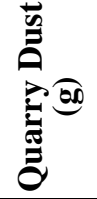 & 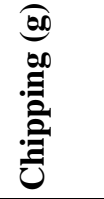 & 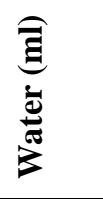 & $\begin{array}{l}\widehat{\widehat{\Xi}} \\
\text { 壱 }\end{array}$ & $\begin{array}{l}\widehat{\widehat{\mathbf{g}}} \\
\hat{\hat{\theta}}\end{array}$ \\
\hline Control & 1030 & 207 & 413 & 187 & 70 & 0 & 0 \\
\hline $3 \%$ of EF Bacteria & 1030 & 207 & 413 & 187 & 67.9 & 2.1 & 0 \\
\hline $5 \%$ of BSP Bacteria & 1030 & 207 & 413 & 187 & 66.5 & 0 & 3.5 \\
\hline
\end{tabular}

\section{Results and Discussion}

\subsection{Growth curve of bacteria Enterococcus faecalis (EF) and Bacillus sp (BSP)}

The growth curve was used to determine the optimum growth for the bacteria to acclimatize in SCBQD environment condition. Daily measurement of Optical Density (OD) for 21 consecutive days was measured in order to provide growth curve for the bacteria as shown in Fig. 1. 


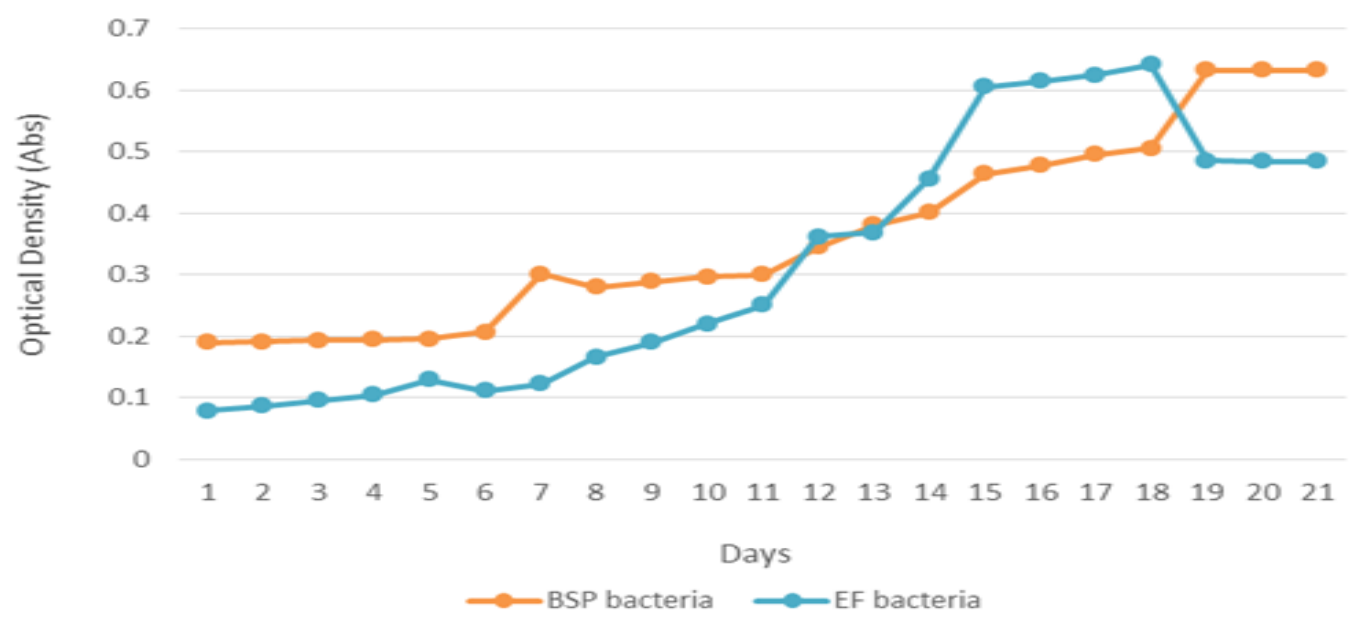

Fig. 1 - Growth curve of bacteria Enterococcus faecalis (EF) and Bacillus sp (BSP)

According to the growth curve as shown in Fig. 1, the highest optical density rate recorded is between 17 to 18 days of growth for EF bacteria and 18 to 19 days of growth for BSP bacteria. Both bacteria strains have specific optimum value. This condition shows that both bacteria have maximum growth on certain day. Therefore both bacteria will be grown and added to concrete after 17-18 days for EF bacteria and 18-19 days for BSP bacteria. However, when continuing to the 20-21days for BSP bacteria and 19-21days for EF bacteria, a rapid declination for both types of bacteria were shown. This scenario is called inactive and die phase of bacteria due to depletion of nutrient provided in nutrient broth liquid during acclimatization process. The growth curve of both bacteria strains were in line with theoretical bacterial growth curve De Muynck et al., (2008) and (Irwan \& Othman, 2013).

According to Siddique and Chahal (2011), logarithmic phase refers to rapid growth of bacteria where the nutrients are actively being used by the bacteria. Therefore the chosen ranges of bacteria growth are suitable to be used in preparing the sample of SCBQD. The bacteria had to undergo 17th-18th for EF and the 18th-19th for BSP consecutive days of shaking in orbital shaker before being used in SCBQD manufacturing. Log phase is known as condition that bacteria performance and activity are high. Therefore, in order to have an optimum result for this study, both bacteria used should be prepared at logarithmic phase as shown in the growth curve of bacteria in Fig. 1

\subsection{Average Harden Density of SCBQD}

Harden density is an essential parameter which is used to control the quality of engineering materials. Control SCBQDs and specimen SCBQDs are cast separately due to the bacterial proportion. In order to reduce major variation among SCBQD mix density checking is applied to ensure the quality and strength of SCBQDs. Fig. 2 shows the average harden density of SCBQDs.

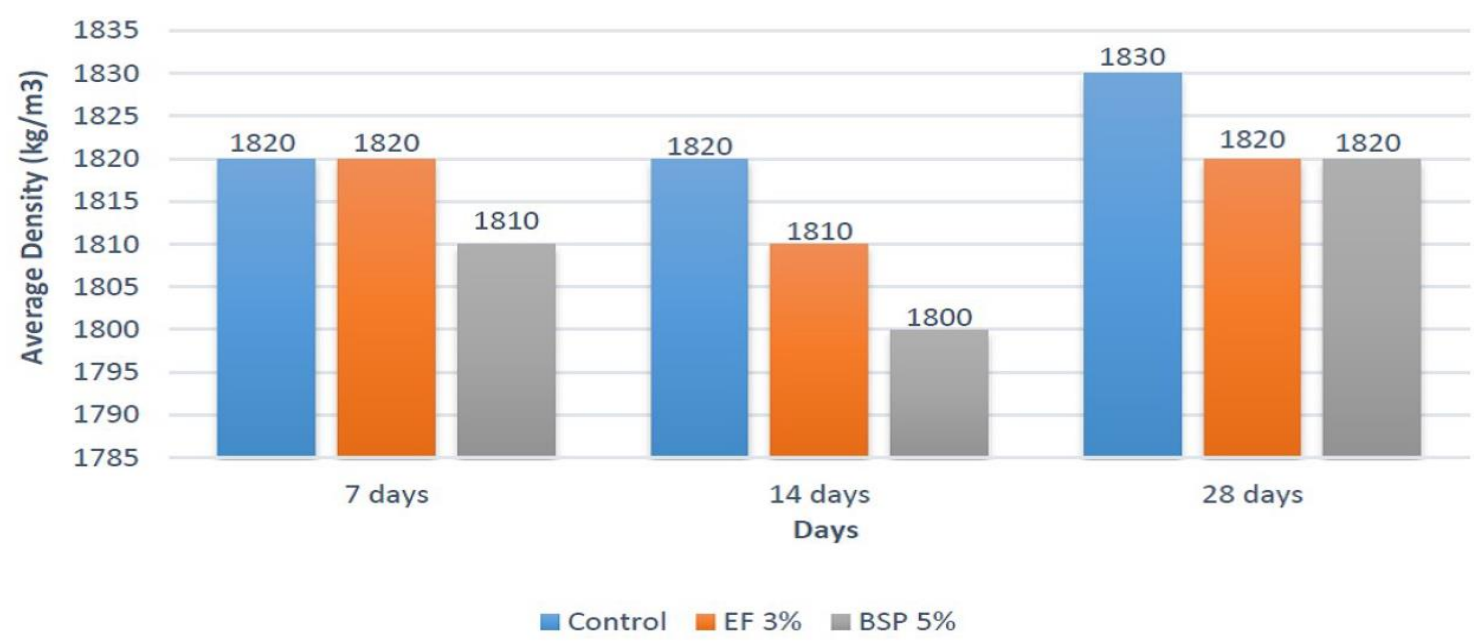

Fig. 2 - Average Harden Density of SCBQD 
Fig. 2 shows average harden density of SCBQD samples for control, EF 3\% and BSP 5\% before it subjected to experimental testing along 7 to 28 days. In general trend of the samples were decreasing after 14 days and increasing at 28 days.

At 7 days, average harden density of SCBQD control is $1820 \mathrm{~kg} / \mathrm{m}^{3}$, while EF $3 \%$ is $1820 \mathrm{~kg} / \mathrm{m}^{3}$ and SCBQD with BSP $5 \%$ is $1810 \mathrm{~kg} / \mathrm{m}^{3}$. The highest average value of harden density after curing for 7 days is control sample and $\mathrm{EF}$ 3\% compared to BSP 5\% bacteria. 14 days control SCBQDs remain present the highest average value for harden density which is $1820 \mathrm{~kg} / \mathrm{m}^{3}$ while, EF $3 \%$ and BSP 5\% SCBQDs are $1810 \mathrm{~kg} / \mathrm{m}^{3}$ and $1800 \mathrm{~kg} / \mathrm{m}^{3}$ respectively. At this phase all the SCBQD mixes are portrait similar harden density which is values are slightly closer between each other.

Control SCBQD at day 28 reached the maximum average harden density with $1830 \mathrm{~kg} / \mathrm{m}^{3}$ and the SCBQD with EF $3 \%$ and BSP $5 \%$ are similar to each other which recorded $1820 \mathrm{~kg} / \mathrm{m}^{3}$. It can be concluded that harden density for this experiment in the range of $1800-1830 \mathrm{~kg} / \mathrm{m}^{3}$. The different among all samples is in the range of $10-30 \mathrm{~kg} / \mathrm{m}^{3}$. Addition of bacteria in this study resulted to no significant different in the concrete density. Overall average density obtained was linear to one another which provide consistent in SCBQDs quality.

\subsection{Compressive strength}

Compressive strength test was conducted by crushing $100 \times 100 \times 100 \mathrm{~mm}$ of mortar cubes. Compressive strength of control mortar cubes were compared with mortar that contain 5\% BSP and 3\% EF bacteria. A total of 27 cubes of mortar were tested and cured in water container to undergo the curing process. Specimens were tested at the age of 7 th, 14th, and 28th days after curing. All data and the average results of specimens are presented as shown in Table 2 and Fig. 3.

Table 2 - Compressive strength of hardened mortar

\begin{tabular}{cccc}
\hline Type of mortar & \multicolumn{3}{c}{ Compressive strength (MPa) } \\
& $\mathbf{7}$ days & $\mathbf{1 4}$ days & 28 days \\
\hline Control & 1.68 & 2.25 & 3.30 \\
3\% of EF Bacteria & 2.16 & 2.61 & 3.57 \\
5\% of BSP Bacteria & 2.46 & 3.49 & 4.90 \\
\hline
\end{tabular}

The mortar that contains 5\% of BSP bacteria obtained higher value of compressive strength compared to the mortar with $3 \%$ of EF Bacteria and also the control mortar. $2.46 \mathrm{MPa}$ value of the compressive strength was achieved by mortar with addition 5\% of BSP Bacteria at age of 7 days which is the highest average compressive strength compared to the other type of mortar. The lowest compressive strength value at the age of 7 th days was obtained by the control mortar without any addition of bacteria which is $1.68 \mathrm{MPa}$.

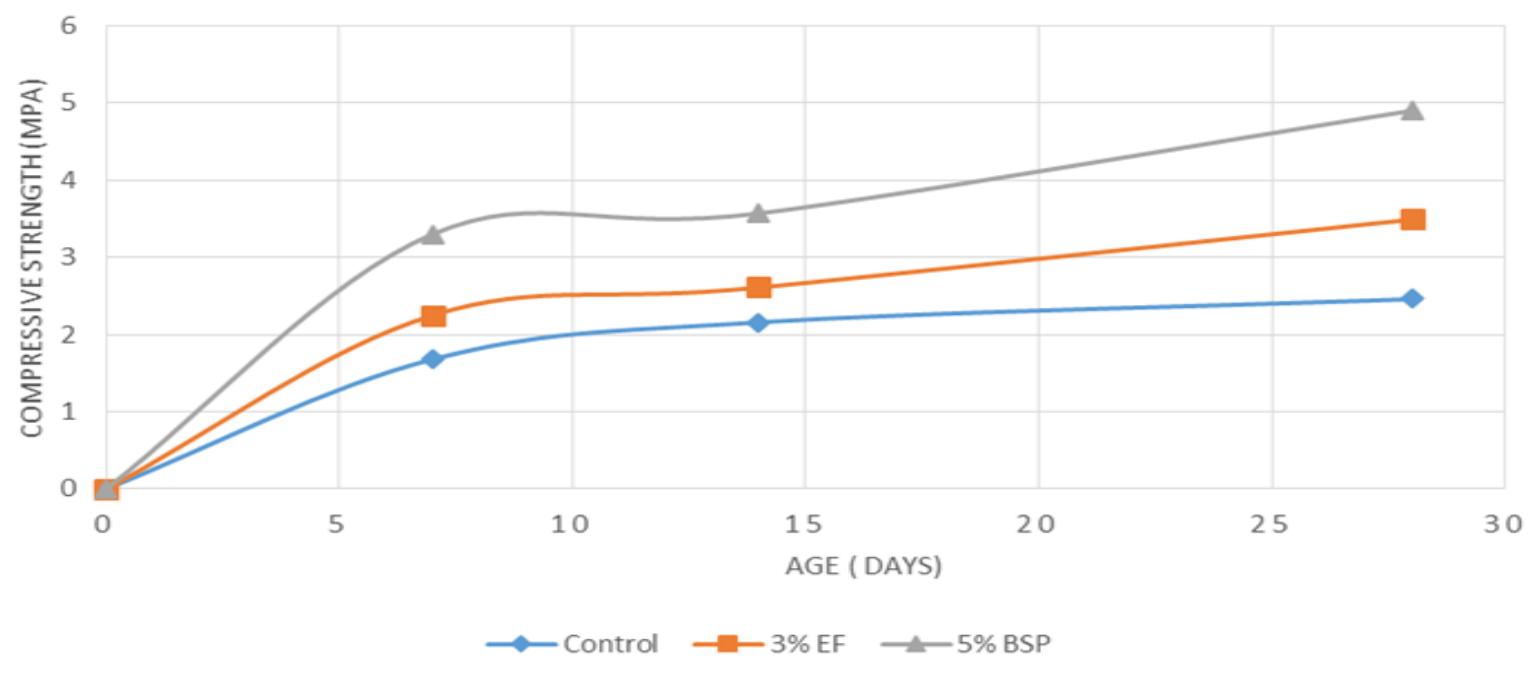

Fig. 3 - Compressive strength development 
Data plotted in Fig. 3 shows that compressive strength is proportional to the curing age of the sample. As the curing time samples increased from day 7 th to $28^{\text {th }}$, the compressive strength value of the sample also increased. The average compressive strength obtains for mortar with $3 \%$ of EF Bacteria increased $21 \%$ with $2.16 \mathrm{MPa}$ at 7 days to $2.61 \mathrm{MPa}$ at 14th days of curing age. The highest compressive strength value obtain at 14th days of curing age is from the mortar with addition of 5\% BSP Bacteria with $3.49 \mathrm{MPa}$ which is increase $42 \%$ from 7 th days of curing age. From 7 th days to 14th days of curing age, the control mortar result for compressive strength remains lowest with $2.25 \mathrm{MPa}$ compared to the mortar with EF and BSP bacteria.

At 28 days of curing age, the highest value of compressive strength test obtains from mortar with addition $5 \%$ of BSP Bacteria was $4.90 \mathrm{MPa}(48.8 \%$ increment). On the other hand, for the mortar contain of EF Bacteria, the percentage of compressive strength increased from 7, 14 and 28 days of curing age with $21 \%, 21 \%$ and $37 \%$ respectively.

It can be concluded that, the mortar with addition of $5 \%$ of BSP Bacteria gain the highest value of compressive strength test compared to other samples. The percentage of compressive strength increase as the days curing age increased for both samples with bacteria addition. Performance of BSP bacteria is higher than EF bacteria in playing its role for increasing compressive strength. The compressive strength result from this study was in line with previous research conducted by Ghosh et al. (2005). According to Chahal et al. (2012), usage of bacteria in concrete increased compressive strength by deposition of calcium carbonate in concrete pores.

\subsection{Carbonation}

Carbonation test was done using a phenolphthalein indicator solution (1 gm phenolphthalein dissolved in $100 \mathrm{ml}$ high purity ethanol). The solution was sprayed on fresh and evenly broken SCBQD surface as shown in Fig. 4. When the SCBQD samples is in alkaline condition, with $\mathrm{pH}>9.5$ a reddish purple color will be obtained as shown in Fig. 5 . Colorless edge indicated that concrete was already carbonated and the corresponding depth was measured with a ruler.

Fig. 6 shows carbonation depth between control SBCQD and the SCBQD contain EF 3\% and BSP 5\% bacteria. Based on carbonation depth results for 7 days, the carbonation depth values are slightly different between control and other specimens which is for control is $5.0 \mathrm{~mm}$, EF $3 \%$ is $3.3 \mathrm{~mm}$ and BSP 5\% is $2.3 \mathrm{~mm}$. At 14 days, the carbonation depth values are slightly closer between control and other specimens which is for control is $8.3 \mathrm{~mm}$, EF $3 \%$ is $7.3 \mathrm{~mm}$ and BSP 5\% is $5.6 \mathrm{~mm}$. While at 28 days, the carbonation depth for control is $15.0 \mathrm{~mm}$, EF $3 \%$ is $13.6 \mathrm{~mm}$ and BSP $5 \%$ is $12.0 \mathrm{~mm}$.

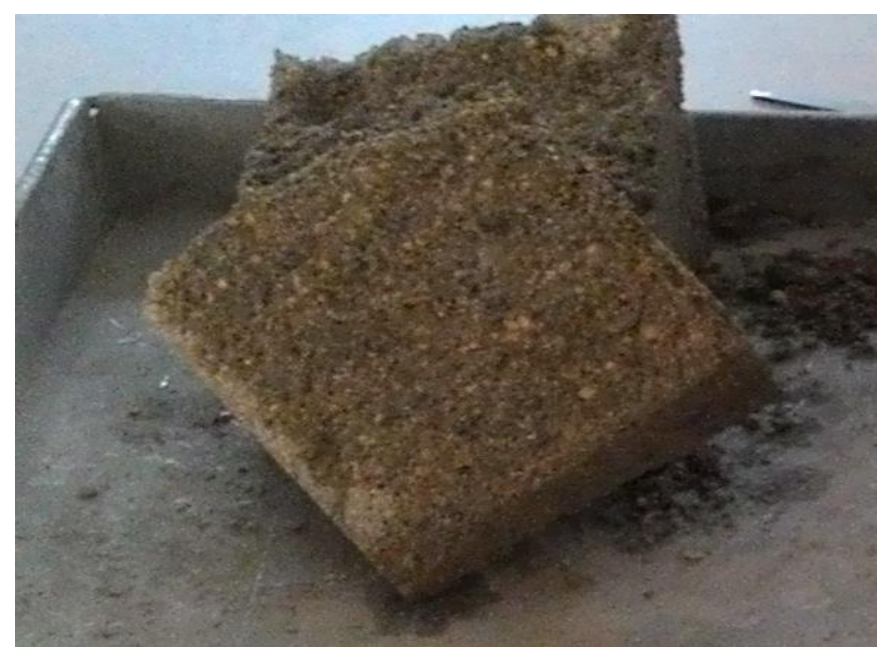

Fig. 4 - The outlook of sliced SCBQD sample before spray phenolphthalein indicator solution 


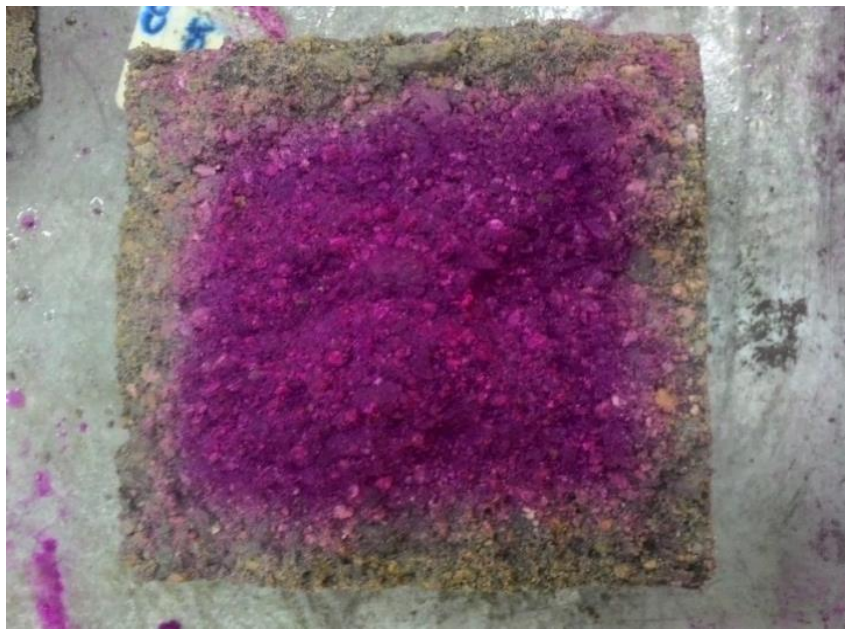

Fig. 5 - The outlook of sliced BSCQD sample after sprayed phenolphthalein indicator solution

Comparison was made between control SCBQD and bacteria SCBQD. Bacteria SCBQDs always experienced the lower carbonation depth at 7 day, 14 day and 28 day. Meanwhile, among all SCBQD samples, BSP 5\% SCBQD had lowest carbonation depth at 7, 14 and 28 days. The graph shows that the SCBQD contain of 5\% Bacillus sp (BSP), has overall lower carbonation depth.

Compared to control SCBQD, carbonation depth of SCBQD with EF 3\% has reduction of 34\% at 7 days, reduction to $9.6 \%$ at 14 days and reduction to $9.3 \%$ at 28 days. The carbonation depth of SCBQD with BSP 5\% has reduction of $54 \%$ at 7 days, reduction of $24 \%$ at 14 days and reduction of $20 \%$ at 28 days. Among three different mix of SCBQD, the SCBQD with BSP 5\% had a greater reduction of carbonation depth compared to control.

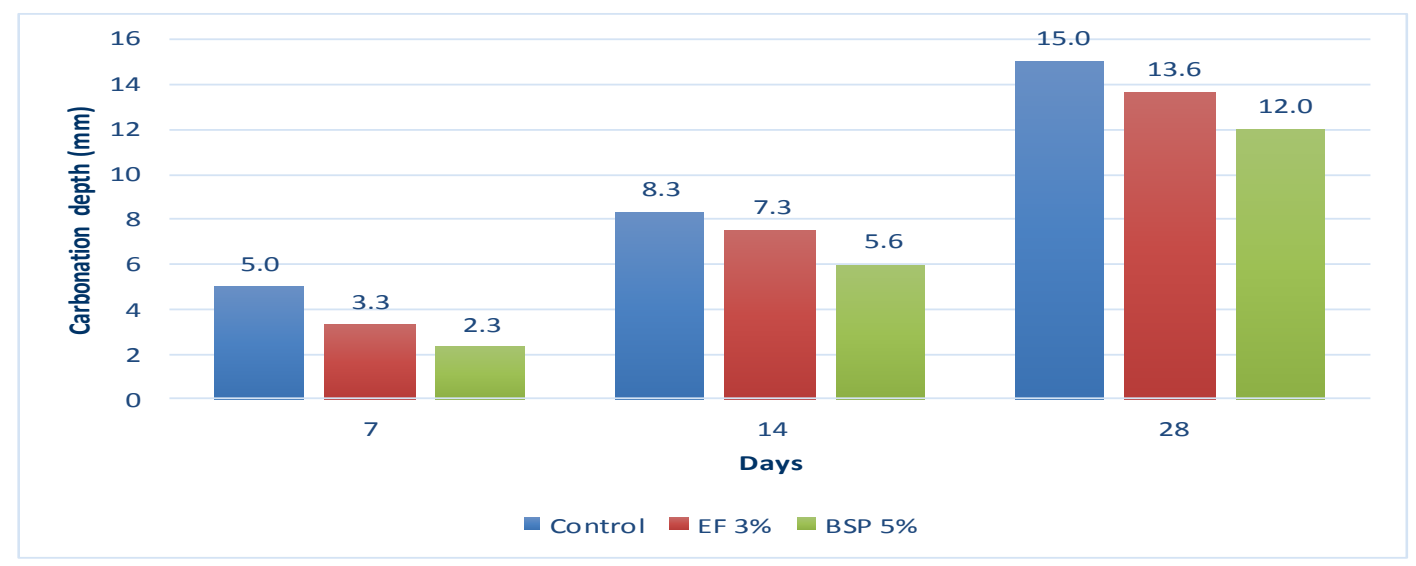

Fig. 6 - Carbonation Depth at different curing day

Fig. 6 shows that the carbonation depth increased gradually with time. Speed of carbonation depends on how fast carbon dioxide or the carbonate ions can move into SCBQD and react with the cement paste. The highest rate of carbonation normally occurs at a relative humidity between 50\% to $70 \%$. This situation can be viewed against background of a typical relative humidity of $65 \%$ in an ordinary laboratory (Nevillie, 2002).

Overall carbonation results showed that concrete with bacteria addition resulted to lower carbonation depth compared to control samples (without bacteria). The resistance of concrete to carbonization is one of an important indicator in measuring concrete durability. Experiments also showed that control concrete without bacteria resulted to higher carbonation and lower compressive strength (as in Fig 3 and Fig 6). Previous studies also proven that concrete with high carbonation depth showed lower compressive strength (De Muynck et al., 2008).

\subsection{Initial rate of suction (IRS)}

IRS test was done according to ASTM C1585 - 04. This test is a measurement on how quickly the water is being absorbed through the SCBQD in 1 minute.

Graph in Fig. 7 shows relationship between IRS values and days of testing. Samples of EF 3\% and BSP 5\% of SCBQDs have shown an effective decrease of IRS after 28 days. A reduction trend of results had proven that the effect of bacteria toward SCBQD and caused decreased of IRS value from time to time because of closing of pores at surface 
layer of SCBQD. Previous research found that calcium carbonate precipitation decreased concrete pores and reduced rate of water passing through concrete (Lohani et al., 2012).

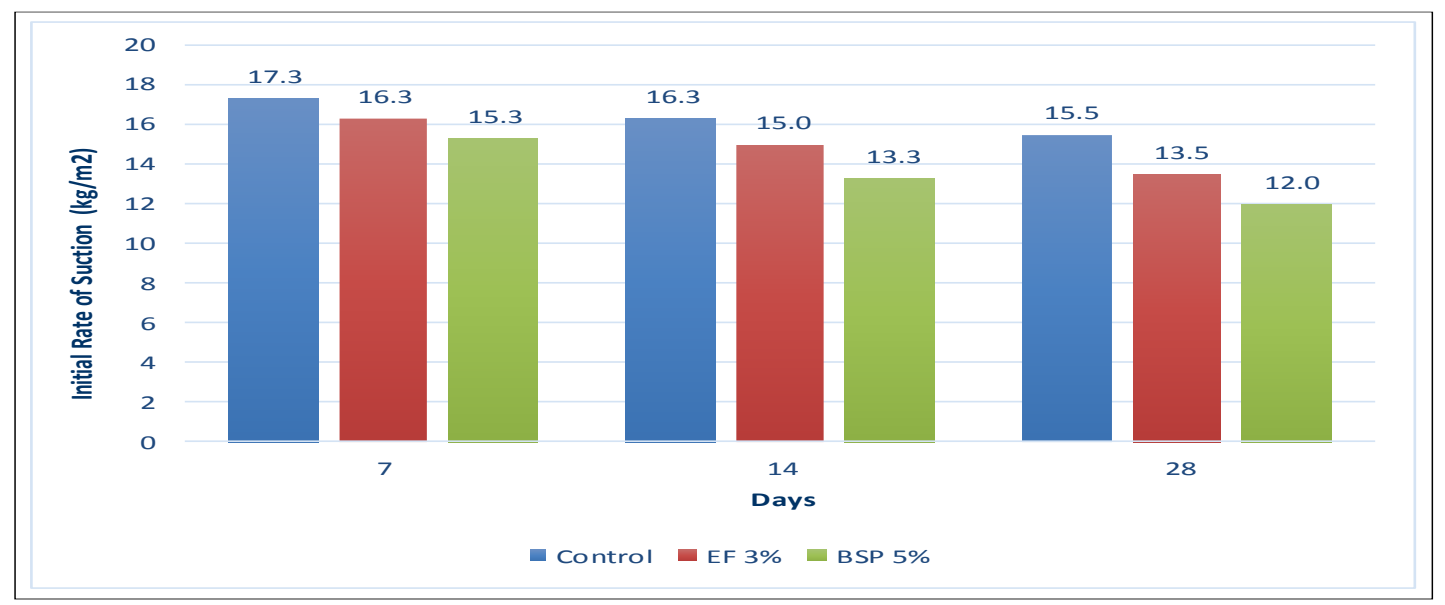

Fig. 7 - Relationship between the IRS values and days

Comparison of IRS was made after 28 days for SCBQD with control sample. EF 3\% SCBQD has shown the reduction of $12.9 \%$ and $\mathrm{BSP} 5 \% \mathrm{SCBQD}$ has shown the reduction of $22.6 \%$. Among control, EF $3 \%$ and $\mathrm{BSP} 5 \%$ SCBQDs, the BSP 5\% SCBQD has shown the greater effective to resist water penetrate into SCBQD. The addition of bacteria in the concrete showed that concrete pores had been seen sealed by calcium carbonation precipitation and resulted to prevent initial rate for water suction (Day, Ramakrishnan \& Bang, 2003).

\subsection{Water absorption}

Data for water absorption percentage at 7, 14 and 28 days are presented in Table 3 and Figure 8.

Table 3 - Water absorption (\%) at 7, 14, and 28 days

\begin{tabular}{cccc}
\hline Type of mortar & \multicolumn{3}{c}{ Maximum Water Absorption (\%) } \\
\cline { 2 - 4 } & $\mathbf{7}$ days & 14 days & 28 days \\
\hline Control & 13.88 & 13.54 & 14.38 \\
3\% of EF Bacteria & 10.19 & 13.07 & 12.22 \\
5\% of BSP Bacteria & 12.18 & 12.07 & 12.02 \\
\hline
\end{tabular}

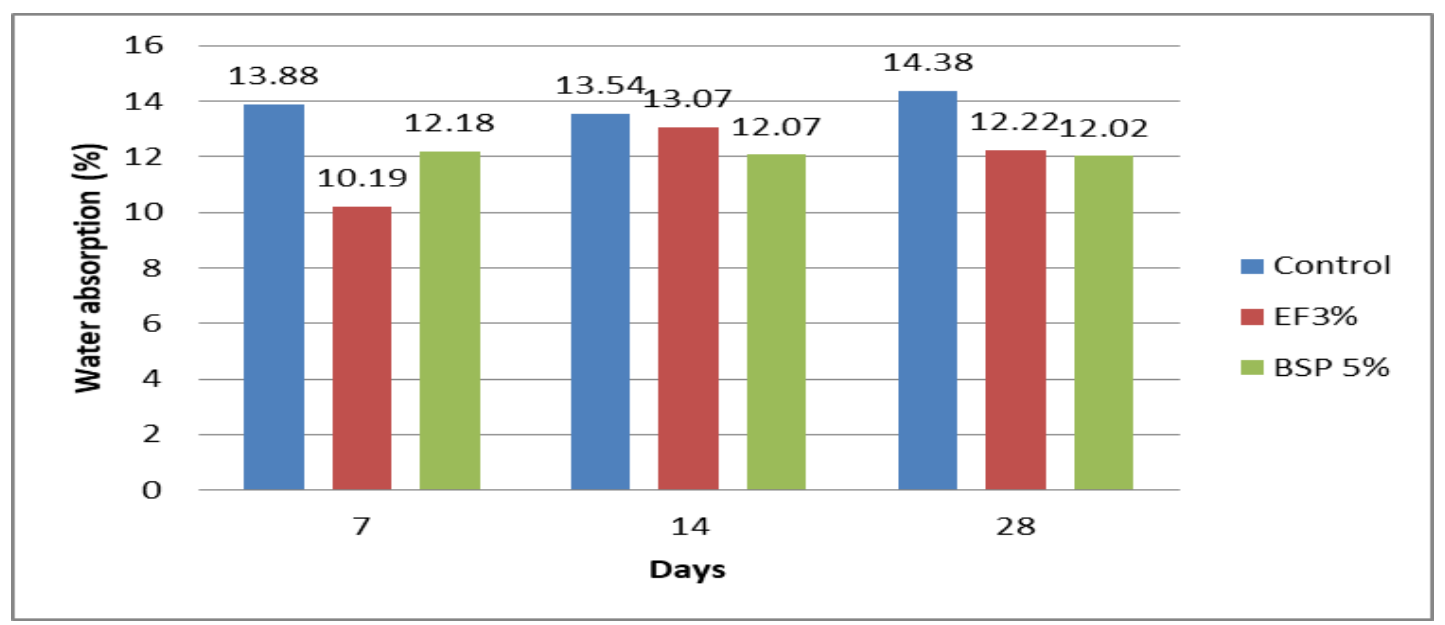

Fig. 8 - Water absorption at 7, 14 and 28 days 
Fig. 8 shows water absorption percentage for control, SCBQD 3\% EF bacteria and SCBQD 5\% BSP bacteria at 7 , 14 and 28 days.

Results after 28day revealed that maximum percentage of water absorption in control samples is $14.38 \%$, while the SCBQD with $3 \% \mathrm{EF}$ bacteria is $12.22 \%$ and SCBQD with 5\% BSP bacteria is $12.02 \%$. The absorption of water from $1 / 2$ hours until 4 hours found that more water absorb to control compared to SCBQD with 3\% EF bacteria and 5\% BSP bacteria.

Based on the results, it is proved that, the addition of bacteria reduce the water absorption. Reduction of water adsorption is higher in MCQD with 5\% BSP bacteria compared to 3\% EF bacteria. The addition of bacteria cause $\mathrm{CaCO}_{3}$ precipitation at concrete pore thus reducing water absorption in MCQD. The results is in agreement with Chahal et al., (2012) and Siddique (2011) where addition of bacteria reduced water absorption of concrete properties with formation of calcite through microbial induced precipitation.

\section{Conclusions}

This study proved that the addition of bacteria improved physical and mechanical properties test namely compressive strength, carbonation, initial rate of suction and water absorption in Sand Cement brick containing Quarry Dust. Addition of 5\% of BSP resulted to higher compressive strength compared to $3 \%$ of EF. It also resulted to decreasing of carbonation, initial rate of suction and water absorption.

\section{Acknowledgement}

This research was supported by RMC-Research Fund, Universiti Tun Hussein Onn Malaysia (UTHM) under MDR (VOT No. H486) and The Ministry of Higher Education Malaysia (MOHE).

\section{References}

Anneza, L. H., Irwan, J. M., Othman, N., \& Alshalif, A. F. (2016). Identification of bacteria and the effect on compressive strength of concrete. MATEC Web of Conferences, 47, 01008

Arunachalam, K. D., Sathyanarayanan, K. S., Darshan, B. S. \& Raja, R. B. (2010). Studies on the characterisation of Biosealant properties of Bacillus sphaericus. International Journal of Engineering Science and Technology, 2(3), 270277

Chahal, N., Siddique, R., \& Rajor, A. (2012). Influence of bacteria on the compressive strength, water absorption and rapid chloride permeability of concrete incorporating silica fume. Construction and Building Materials, 37, 645- 651

Day, J. L., Ramakrishnan V. \& Bang S.S. (2003). Microbiologically induced sealant for concrete crack remediation. Proceeding. of 16th Engineering Mechanics Conference, Seattle, America

De Muynck, W., Cox, K., De Belie, N. \& Verstraete, W. (2008). Bacterial carbonate precipitation as an alternative surface treatment for concrete. Construction and Building Materials, 22(5), 875-885

Ghosh, P., Mandal, S., Chattopadhyay, B. D. \& Pal S. (2005). Use of microorganism to improve the strength of cement mortar. Cement and Concrete Research, 35(10), 1980-1983

Irwan, J. M. \& Othman, N. (2013). An overview of bioconcrete for structural repair. Applied Mechanics and Materials, $389,36-39$

Irwan, J. M., Anneza, L. H., Othman, N., Husnul T. \& Alshalif, A. F. (2016). Isolation and identification of concrete environment bacteria. IOP Conference Series: Materials Science and Engineering, 136, 012088

Joseph, O. U., Maurice, E. E., \& Godwin, A. A. (2012). Compressive strength of concrete using lateritic sand and quarry dust as fine aggregate. ARPN Journal of Engineering and Applied Sciences, 7(1), 81-92

Lohani, T. K., Padhi, M., Dash K.P. \& Jena, S. (2012). Optimum utilization of Quarry dust as partial replacement of sand in concrete. Int. Journal of Applied Sciences and Engineering Research, 1(2), 391-404

Manning, D. \& Vetterlein, J. (2004). Exploitation and use of quarry fines. MIRO Final Report, Manchester, USA: Mineral Solutions Ltd 
Nevillie, A. M. (2002). Properties of Concrete (Fourth and Final Edition), Essex: Pearson Education Limited

Othman, N., Irwan, J. M., Zamer, M. M., Anneza, L. H., Tambunan, T. \& Alshalif, A. F. (2017). Acclimatization process of ureolytic bacteria (UB) with soil condition for interlocking compressed earth block (ICEB) in improving compressive strength properties. Advanced Science Letters, 23(5), 4341-4343

Ramachandran, S. K., Ramakrishnan, V. \& Bang, S. S. (2001). Remediation of Concrete using micro-organisms. ACI Materials Journal, 98(1), 3-9

Siddique, R. \& Chanal, N. K. (2011). Effect of Ureolytic Bacteria on concrete properties. Construction and Building Materials, 25, 3791-3801

Sivakumar, A. (2011). Characteristic studies on the mechanical properties of quarry dust addition in conventional concrete. Journal of Civil Engineering and Construction Technology, 2(10), 218-235

Sukesh, C., Krishna, K. B., Sai Teja, P. S. L. \& Rao, S. K. (2013). Partial replacement of sand with quarry dust in concrete. International Journal of Innovative Technology and Exploring Engineering, 2(6), 2278-3075

Ventakarama Reddy, B. V. \& Jagadish, K. S. (2003). Embodied energy of common and alternative building materials and technologies. Energy and Building, 35, 129-137 